\title{
PENGARUH SOCIAL MEDIA MARKETING, E-SERVICE QUALITY, DAN REVIEW CONTENT TERHADAP MINAT BELI PADA UMKM PRODUK ORGANIK
}

\author{
Bagus Satriyo \\ Institut Agama Islam Negeri Salatiga \\ bagusksatriya@gmail.com \\ Yeni Indriana \\ Institut Agama Islam Negeri Salatiga \\ yenianna634@gmail.com \\ Musalim Ridlo \\ Institut Agama Islam Negeri Salatiga \\ gusmusa19@gmail.com
}

\begin{abstract}
Advances in information technology and digital-based economy expand the potential for entrepreneurship. Market segmentation becomes more extensive due to an online marketplace to sell goods and services. Online marketplace company needs an edge to compete with other similar businesses. Nyayur uses various marketing strategies to be able to compete. This study aimed to determine the influence of social media marketing, review content, and e-service quality on buying interest among users of Nyayur in Salatiga. The data is collected using purposive sampling techniques with questionnaires distributed directly to fifty users of Nyayur. The data obtained were processed using IBM SPSS statistics 25. The results showed that social media marketing, $e$ service quality, and content review do not influence purchase intention. This research can be an additional consideration for Nyayur.com in improving the quality of its operations, where this research provides factual evidence from consumers regarding their perception of Nyayur.com. So that this research can be used as material for monitoring and evaluation (Monev) of e-commerce platforms to improve the quality and professionalism of work, especially for Nyayur. com. Services using social media promotions can update their marketing strategy, considering that most users are housewives who do not actively use social media in the form of platforms. E-service quality can provide product consulting services for fruit and vegetables via calls or Whatsapp. Reviewing content on nyanyur.com is essential to support the progress of its performance. Consumers who provide the best reviews can be rewarded to help the nyayur.com application in the future.
\end{abstract}

Keywords: e-service quality; organic food; purchase intention; review content; social media marketing.

\section{PENDAHULUAN}

Era industri 4.0 identik dengan penggunaan teknologi informasi dalam segala bidang kehidupan baik individu, swasta maupun pemerintah. Salah satu bentuknya yaitu penggunaan internet di bidang ekonomi. Penggunaan internet di Indonesia mengalami peningkatan sebesar 10,12\% pada tahun 2018 yaitu sebanyak 171.170 .000 atau 64,8\% dari total penduduk (tekno.kompas.com, 2019). Peningkatan tersebut melahirkan potensi bisnis dengan basis teknologi atau startup. Startup adalah perusahaan yang bekerja untuk memecahkan permasalahan, di mana solusinya bersifat tidak pasti dan keberhasilan solusi tidak menjadi jaminan (forbes.com, 2019). Sejalan dengan itu, pemerintah Indonesia membuat sebuah gebrakan nasional bagi para millenial melalui Gerakan 1000 Start up Digital Nasional. Gerakan ini diharapkan nantinya mampu membentuk dan melahirkan start upstartup baru yang akan menjadikan Indonesia sebagai negara Digital Energy of Asia. Gerakan ini dilakukan di berbagai kota besar di Indonesia, seperti Jakarta, Bandung, Semarang, Yogyakarta, Malang, Surabaya, Denpasar, Makasar, Pontianak dan Medan (kominfo.go.id, 2019).

Kota Salatiga menjadi salah satu di antara kota yang tidak masuk dalam daftar penyelenggaraan program tersebut, akan tetapi bukan berarti di kota ini tidak mampu tumbuh start up. Salah satunya yaitu Nyayur Indonesia, satu dari sekian startup yang lahir dan tumbuh di Kota Salatiga ini. Fokus dari start up ini adalah menyajikan pelayanan terbaik serta produk yang berkualitas dan higienis bagi seluruh ibu-ibu di Indonesia guna memenuhi kebutuhan gizi harian keluarga (nyayur.com, 2019). Nyayur Indonesia meluncurkan aplikasi Nyayur sebagai platform online marketplace untuk 
pembelian bahan makanan dan bahan pendukungnya, di antaranya sayuran, buah-buahan, bumbu masak, sembako, keperluan mandi dan sebagainya (nyayur.com, 2019). Sebagai start up yang masih baru, Nyayur sadar bahwa mengenalkan produk kepada masyarakat dan pengguna potensial adalah suatu keharusan. Salah satunya dengan menggunakan social media marketing, yaitu strategi pemasaran yang mendorong individu untuk melakukan promosi melalui situs web, produk atau layanan mereka melalui saluran sosial online dan untuk berkomunikasi dengan memanfaatkan komunitas yang jauh lebih besar yang memiliki kemungkinan lebih besar untuk melakukan pemasaran dari pada melalui saluran periklanan tradisional (Mileva \& Millianyani, 2018).

Nyayur.com menggunakan dua platform untuk memasarkan produknya yaitu Facebook dan Instragram. Hal tersebut diharapkan mampu mendorong Nyayur untuk dikenal lebih luas oleh masyarakat Indonesia dan dunia (nyayur.com, 2019). Indika \& Jovita (2017) serta Giri \& Millianyani (2015) memaparkan social media marketing berpengaruh positif dan signifikan terhadap minat beli. Hal ini berarti memasarkan dengan social media meningkatan minat beli secara signifikan. Sedangkan Kurniawati \& Nugraha (2015), menyatakan bahwa social media marketing yang dilakukan hanya sedikit menimbulkan hasrat minat beli. Artinya, social media marketing hanya menimbulkan pengaruh kecil dan bahkan tidak ada pada kenaikan minat beli.

Selain memasarkan melalui social media, Nyayur juga melengkapi aplikasi dengan fitur review dan rating yang dapat diisi oleh penggunanya. Penilaian pengguna aplikasi jelas terlihat di halaman utama aplikasi Nyayur (nyayur.com, 2019). Ichsan (2018) menjelaskan consumer rating sebagai suatu hal yang sama dengan review namun opini yang diberikan oleh konsumen dalam bentuk skala yang ditentukan. Rating pada Nyayur berupa bintang, di mana lebih banyak bintang menunjukan nilai lebih baik. Consumer review sebagai suatu opini atau pengalaman yang diberikan oleh konsumen dari layanan yang didapatkan maupun produk dari suatu bisnis.

Farki (2016) \& Ichsan (2018) menjelaskan review content memiliki pengaruh positif dan signifikan terhadap minat beli. Maksudnya, review content dari pengguna mampu memberi kesan positif kepada calon konsumen potensial dan meningkatkan minat beli. Sedangkan, Hasan \& Setyaningsih (2015) menyatakan online review dalam review content tidak berpengaruh signifikan terhadap minat beli konsumen. Artinya, review content yang dibuat oleh pengguna memiliki pengaruh kecil bahkan mendekati tidak ada terhadap minat beli.

Setelah penggunaannya, setiap konsumen akan mendapatkan pengalaman layanan yang diberikan Nyayur dalam bentuk kualitas pelayanan secara elektronik atau lebih dikenal dengan sebutan eservice quality. Pelayanan ini hanya dapat dirasakan oleh konsumen setelah menggunakan layanan Nyayur (nyayur.com, 2019). Andrew (2019) menjelaskan e-service quality dalam interaksi pengguna dengan website baik apabila website secara efektif dan efisien memfasilitasi pengalaman belanja pengguna. Pengguna melakukan penelusuran katalog produk melakukan pembelian hingga proses penyerahan produk. Seluruh pelayanan tersebut dilakukan dengan sistem yang tidak terlihat, akan tetapi mampu dirasakan oleh konsumen.

Maulana \& Kurniawan (2014) serta Nasir \& Harti (2017) mengatakan bahwa e-service quality berpengaruh positif bahkan signifikan terhadap minat beli. E-Service Quality yang baik pada layanan digital yang diberikan mampu miningkatkan minat beli para pengguna. Barriyah \& Suyanto (2019), mengutarakan e-service quality tidak memiliki pengaruh signifikan terhadap minat beli konsumen melalui indikatornya yaitu reliability dan personalization. Hal tersebut karena sifat pribadi masingmasing berbeda sehingga tidak selalu dari waktu ke waktu memiliki keinginan untuk berminat membeli barang di online shop.

Penelitian ini bertujuan untuk menguji pengaruh social media marketing, e-service quality, dan review content terhadap minat beli pada UMKM produk organik. 


\section{KAJIAN PUSTAKA DAN PENGEMBANGAN HIPOTESIS}

\section{Perilaku Konsumen}

Perilaku konsumen adalah studi tentang bagaimana individu, grup dan organisasi memilih, membeli, menggunakan dan membuang barang, jasa, ide dan pengalaman untuk memuaskan kebutuhan dan keinginannya (Kotler \& Keller, 2016). Fajrina \& Sastika (2016), mengutarakan tingkah laku konsumen, di mana mereka dapat melakukan pencarian untuk membeli, menggunakan, mengevaluasi dan memperbaiki suatu produk dan jasa. Pandangan tradisional pemasaran terhadap proses pembelian atau adopsi menggambarkannya sebagai suatu seri atau mata rantai kejadian kognitif yang diikuti oleh perilaku tunggal, biasanya disebut adopsi atau pembelian (Peter \& Olson, 1999: 260). Model urutan Perilaku Konsumen sebagai berikut. (1) Kontak informasi, terjadi ketika konsumen terlibat langsung dengan informasi tentang produk, toko atau merek. (2) Akses pendanaan, dalam tahapan ini, uang adalah media utama dalam pertukaran konsumen, di mana konsumen harus mengakses media ini dalam satu bentuk atau bentuk lainnya sebelum pertukaran terjadi. (3) Kontak toko, tugas utama para pengecer adalah bagaimana caranya membawa konsumen ke dalam toko untuk melakukan transaksi jual beli. (4) Kontak produk, bagaimana meningkatkan dan memelihara pelanggan-pelanggan tertentu, para produsen terutama berkepentingan dengan kebutuhan tertentu, pembelian. (5) Transaksi, yaitu dana konsumen dipertukarkan dengan produk atau jasa (6) Konsumsi, suatu kegiatan konsumsi atau penggunaan. (7) Komunikasi, pemasar ingin agar konsumennya berkomunikasi dengan dua maksud utama, yaitu menyediakan informasi pemasaran kepada perusahaan dan memberitahu konsumen potensial tentang produk dan mendorong mereka untuk membelinya (Peter \& Olson, 1996: 268).

\section{Minat Beli}

Secara umum, minat beli diartikan sebagai keinginan seseorang untuk membeli kembali produk pada perusahaan tertentu, selain itu merupakan bentuk respon positif dari pelanggan terhadap kualitas produk (Ramadhan \& Santosa, 2017). Pada suatu transaksi jual beli, terdapat faktor yang memengaruhi minat konsumen membeli barang, di antaranya sebagai berikut. (1) Faktor luar atau faktor yang memengaruhi individu seperti lingkungan kantor, keluarga, lingkungan sekolah dan lain sebagainya. (2) Faktor dalam diri individu yang memengaruhi seperti kepribadian sebagai calon konsumen (Pramono \& Ferdinand, 2012). Minat beli dapat diukur dengan indikator-indikator sebagai berikut. (1) Transaksional yaitu kecenderungan seseorang untuk membeli produk. (2) Referensial yaitu kecenderungan seseorang untuk mereferensikan produk kepada orang lain. (3) Preferensial yaitu minat yang menggambarkan perilaku seseorang yang memiliki preferensi utama pada produk tersebut. (4) Eksploratif yaitu minat ini menggambarkan perilaku seseorang yang selalu mencari informasi mengenai produk yang diminatinya dan mencari informasi untuk mendukung sifat-sifat positif dari produk tersebut (Pramono \& Ferdinand, 2012).

\section{Social Media Marketing}

Social media marketing adalah suatu bentuk pemasaran langsung ataupun tidak langsung yang digunakan untuk membangun kesadaran, pengakuan, daya ingat dan tindakan untuk merek, bisnis, produk, orang atau entitas lainnya dan dilakukan dengan menggunakan alat dari web sosial seperti blogging, microblogging, social networking, social bookmarking dan content sharing. Social media marketing dapat diukur dengan indicator sebagai berikut. (1) Content creation yaitu konten yang menarik menjadi landasan strategi dalam melakukan pemasaran media sosial. (2) Content sharing, yaitu membagikan konten kepada komunitas sosial dapat membantu memperluas jaringan sebuah bisnis dan memperluas online audience. (3) Connecting yaitu jejaring sosial memungkinkan seseorang bertemu dengan lebih banyak orang yang memiliki minat yang sama. (4) Community building yaitu web sosial merupakan komunitas online besar individu di mana terjadi interaksi antar manusia yang tinggal di seluruh dunia dengan menggunakan teknologi (Mileva \& Millianyani, 2018).

Salah satu saluran komunikasi adalah media massa (impersonal) seperti media cetak, siaran, atau elektronik. Pada dasarnya, komunikasi pemasaran perusahaan dirancang agar konsumen mengetahui produk, mendorong pembelian atau komitmen, menghasilkan sikap positif terhadap produk, memberi makna simbolis pada produk, atau menunjukkan bagaimana komunikasi ini dapat memecahkan masalah konsumen dengan lebih baik daripada produk pesaing (Schiffman \& Kanuk, 2008). 
Bagus Satriyo, Yeni Indriana, \& Musalim Ridlo. Pelrsan Social Media Marketing, E-Service Quality, dan Review Content terhadap Minat Beli pada UMKM Produk Organik

Kuspriyono \& Nurelasari (2018), Deru \& Cindy (2017), Fajriani \& Sastika (2016), menyatakan bahwa social media marketing berpengaruh positif dan signifikan terhadap minat beli. Berdasarkan uraian tersebut, hipotesis penelitian ini adalah sebagai berikut.

H1: $\quad$ Social media marketing berpengaruh positif terhadap minat beli.

\section{E- Service Quality}

E-service quality dapat diartikan sebagai sebuah website secara efektif dan efisien memfasilitasi dalam hal belanja, melakukan pembelian dan proses penyerahan dari produk dan jasa (Andrew, 2019). Indikator untuk mengukur e-service quality di antaranya adalah sebagai berikut. (1) Website design yaitu tampilan depan yang ditampilkan kepada konsumen dan menjadi hal yang krusial bagi toko online. (2) Reliability yaitu kemampuan dari suatu website untuk memenuhi pesanan dengan benar. (3) Mengirimkan dengan segera dan menjaga informasi pribadi tetap aman. (4) Responsiveness yaitu kecepatan toko online dalam merespon pertanyaan konsumen dan kecepatan navigasi. (5) Trust yaitu kerelaan pelanggan untuk menerima kerentanan dalam sebuah transaksi online berdasarkan ekspektasi-ekspektasi positif pelanggan mengenai perilaku toko online. (5) Personalization yaitu perhatian individu yang diberikan toko online kepada pelanggan, seperti ucapan terima kasih secara personal, ketersediaan area pesan untuk pertanyaan konsumen (Andini, 2016).

Sikap tergantung pada sistem nilai seorang individu yang mewakili standar pribadi baik dan buruk serta benar dan salah (Sudaryono, 2016). Ini sesuai dengan Andrew (2019) dan Nasir \& Harti (2017), Rendi \& Kezia (2014), yang menyatakan bahwa e-service quality berpengaruh positif terhadap minat beli. Berdasarkan uraian tersebut, hipotesis penelitian ini adalah sebagai berikut.

H2: $\quad$ E-service quality berpengaruh positif terhadap minat beli.

\section{Review Content}

Review Content adalah informasi evaluasi dari produk dan layanan yang telah lalu dalam website dan retail, yang mana hal ini diciptakan oleh pelanggan (Mo, 2015). Indikator dalam pengukuran review content adalah sebagai berikut. (1) Description rating salah satu faktor reputasi toko dengan penilaian rating bintang yang fokus pada penjelasan deskripsi produk. (2) Logistics rating salah satu faktor reputasi toko dengan penilaian rating bintang yang fokus pada jaminan ketersediaan produk, dalam hal ini harus selalu ada. (3) Service rating salah satu faktor reputasi toko dengan penilaian rating bintang yang fokus pada pelayanan kepada pengguna. (4) The quantity of picture reviews salah satu jenis review dengan menggunakan gambar yang merefleksikan kualitas sesungguhnya dari sebuah barang, meliputi permasalahan warna, permasalahan ketidaksesuaian spesifikasi atau kualitas dan pengalaman yang baik. (5) The quantity of additional reviews, review ini mengarah ke review ke dua konsumen. Review ini dapat berbentuk teks maupun gambar. (6) The quantity of cumulative reviews, review jenis ini di-post-kan dalam waktu satu bulan. Review meliputi warna, kualitas, spesifikasi, logistik, customer service, dan faktor lainnya (Mo, 2015).

Kredibilitas sumber formal seperti sumber non-profit biasanya memiliki kredibilitas yang lebih tinggi dibandingkan dengan sumber profit. Hal ini karena sumber formal dianggap netral (Schiffman \& Kanuk, 2008). Ini sejalan dengan penelitian yang dilakukan oleh Farki (2016) dan Ichsan (2018) dan Rahman (2021), bahwa consumer online rating and review berpengaruh terhadap minat beli. Berdasarkan uraian tersebut, hipotesis penelitian ini adalah sebagai berikut.

H3: Review content berpengaruh positif terhadap minat beli.

Hubungan antar variabel juga dapat dilihat di Model Penelitian pada Gambar 1. 


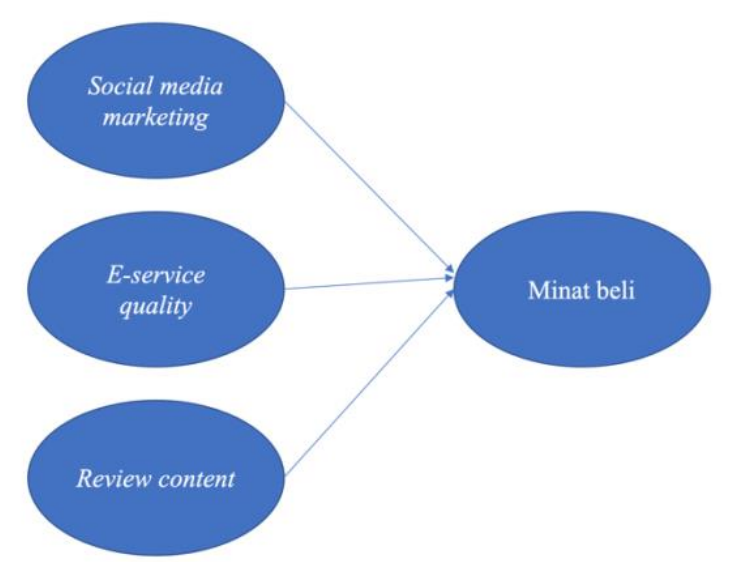

Gambar 1. MODEL PENELITIAN

\section{METODE PENELITIAN}

Penelitian ini menggunakan metode kuantitatif. Objek penelitian ini adalah pengguna yang telah mendownload, kemudian mendaftar, dan menggunakan aplikasi buatan Nyayur Indonesia yaitu Nyayur. Penelitian dilakukan di Kota Salatiga, Provinsi Jawa Tengah, Indonesia sebagai tempat lahir dan berkembangnya start up Nyayur Indonesia. Penelitian dilakukan pada bulan Juli sampai September 2019. Metode pengambilan sampel dalam penelitian ini menggunakan tipe non-probability sampling dengan teknik purposive sampling. Syarat minimal untuk menjadi sampel dalam penelitian ini sebagai berikut. (1) Pengguna Nyayur Indonesia. (2) Telah melakukan transaksi minimal satu kali. Data konsumen Nyayur Indonesia didapat dari pemilik usaha tersebut. Pengumpulan data menggunakan kuesioner yang diberikan kepada responden dengan mendatangi responden ke rumah masing-masing. Jumlah responden adalah 50 orang. Data dianalisis dengan menggunakan analisis regresi linear berganda dengan software IBM SPSS versi 25.

\section{HASIL DAN PEMBAHASAN}

Tabel 1.

HASIL UJI VALIDITAS

\begin{tabular}{lll}
\hline \multicolumn{1}{c}{ Variabel } & Pertanyaan & R Hitung \\
\hline Social media marketing & SMM1 & $.645^{* *}$ \\
& SMM2 & $.599^{* *}$ \\
& SMM3 & $.833^{* *}$ \\
Review content & SMM4 & $.845^{* *}$ \\
& RC1 & $.683^{* *}$ \\
& RC2 & $.627^{* *}$ \\
& RC3 & $.576^{* *}$ \\
& RC4 & $.721^{* *}$ \\
& RC5 & $.797^{* *}$ \\
E-service quality & RC6 & $.715^{* *}$ \\
& ESQ1 & $.815^{* *}$ \\
& ESQ2 & $.906^{* *}$ \\
& ESQ3 & $.734^{* *}$ \\
Minat beli & ESQ4 & $.885^{* *}$ \\
& ESQ5 & $.937^{* *}$ \\
& BI1 & $.790^{* *}$ \\
& BI2 & $.774^{* *}$ \\
& BI3 & $.752^{* *}$ \\
& BI4 & $.727^{* *}$ \\
\hline
\end{tabular}

Sumber: Data diolah (2021) 
Bagus Satriyo, Yeni Indriana, \& Musalim Ridlo. Penrouh Social Media Marketing, E-Service Quality, dan Review Content terhadap Minat Beli pada UMKM Produk Organik

\section{Hasil Uji Validitas}

Dapat dilihat pada tabel 1, seluruh $\mathrm{R}$ Tabel< R hitung, sehingga seluruh item pertanyaan valid.

\section{Uji Reliabilitas}

Cronbach alpha untuk variabel social media marketing, review content, e-service quality dan minat beli berturut-turut adalah 0,$756 ; 0,813 ; 0.885$; dan 0.8 . Nilai cronbach alpha masing-masing variabel> 0,60 . Maka, semua variabel reliabel.

\section{Koefesien Determinasi $\left(\mathbf{R}^{2}\right)$}

Koefisien korelasi (R) sebesar 0,740, artinya terdapat hubungan yang kuat antara variabel bebas dengan variabel terikat. Hal ini dikarenakan nilainya mendekati 1 (satu). Koefisien determinasi (R2) sebesar 0,547, artinya kontribusi variabel bebas memengaruhi variabel terikat sebesar 54,7\%. Sedangkan sisanya sebesar 45,3\% dipengaruhi oleh variabel lain.

\section{Analisis Regresi}

Jika nilai sig > alpha $=0,05(5 \%)$, variabel independen tidak berpengaruh signifikan terhadap variabel dependen. Tabel 2 menunjukkan social media marketing e-service quality dan variabel review content tidak signifikan berpengaruh terhadap minat beli secara parsial. Dengan kata lain, H1, H2, dan H3 tidak terbukti.

Tabel 2.

HASIL UJI REGRESI

\begin{tabular}{cllc}
\hline Jenis Uji & \multicolumn{1}{c}{ Keterangan } & Koefesien & Sig. \\
\hline Uji t & Social media marketing (X1) & .023 & .869 \\
& E-service quality (X2) & .452 & .000 \\
& Review content (Z) & .154 & .180 \\
Uji F & & .547 & .000 \\
R-square & &
\end{tabular}

Sumber: Data diolah (2021)

\section{Pengaruh Social Media Marketing terhadap Minat Beli}

Berdasarkan pada hasil uji regresi yang telah dilakukan, social media marketing tidak berpengaruh signifikan terhadap minat beli ulang terhadap produknya. Ini sejalan dengan penelitian Kurniawati \& Nugraha (2015) yang menyatakan bahwa social media marketing tidak berpengaruh signifikan terhadap minat beli seseorang. Hal ini dikarenakan tidak semua pengguna Nyayur merupakan pengguna media sosial yang aktif. Mayoritas konsumennya adalah ibu rumah tangga dan pegawai swasta di mana mereka mengandalkan rekomendasi dari orang terdekatnya yang sudah menjadi pelanggan. Konsumen tidak mengetahui jika ada promo penjualan produk melalui media sosial milik Indonesian Yours.

\section{Pengaruh E-Service Quality terhadap Minat Beli}

Berdasarkan pada hasil uji regresi yang telah dilakukan, e-service quality tidak berpengaruh signifikan terhadap minat beli ulang terhadap produknya. Ini sejalan dengan penelitian oleh Andrew (2019), Nasir \& Harti (2017), serta Maulana \& Kurniawan (2014), yang menyatakan bahwa kualitas pelayanan terhadap produk berpengaruh terhadap minat beli masyarakat. Pada umumnya, seseorang akan lebih menyukai produk dengan pelayanan yang baik dan profesional (ramah, sopan, ramah). Salah satu faktor yang memengaruhi minat beli konsumen adalah faktor dalam diri individu seperti kepribadian sebagai calon konsumen. Hal ini menunjukkan bahwa pengalaman pribadi yang baik dalam menggunakan layanan digital dapat menjadi faktor dalam meningkatkan minat beli konsumen (Pramono \& Augusty, 2012). 


\section{Pengaruh Review Content terhadap Minat Beli}

Berdasarkan pada hasil uji regresi yang telah dilakukan, review content tidak berpengaruh signifikan terhadap minat beli ulang terhadap produknya. Ini sejalan dengan penelitian yang dilakukan oleh Hasan \& Setyaningsih (2015), yang menyatakan bahwa review online berpengaruh tidak signifikan terhadap minat beli. Review content berbanding lurus dengan pemasaran media sosial. Hal ini dikarenakan mayoritas konsumen pasif dalam menggunakan sosial media terutama membuka aplikasi. Untuk itu, ke depan diharapkan Indonesia dapat memperluas segmentasi konsumen, tidak hanya ibu rumah tangga, tetapi seluruh lapisan masyarakat. Khusunya konsumen yang menggunakan aplikasi nyayur.com.

\section{Implikasi Manajerial}

Penelitian ini dapat menjadi tambahan pertimbangan bagi Nyayur. com dalam meningkatkan kualitas operasionalnya, di mana penelitian ini memberikan bukti faktual dari konsumen mengenai persepsi mereka terhadap Nyayur.com. Sehingga penelitian ini dapat dijadikan sebagai bahan monitoring dan evaluasi (Monev) platform e-commerce untuk meningkatkan kualitas dan profesionalisme kerja khususnya bagi Nyayur, terutama pada: (1) pelayanan menggunakan promosi menggunakan media sosial dapat diperbaharui stratgi pemasarannya, mengingat pengguna kebanyakan ibu-ibu rumah tangga yang tidak aktif menggunakan media sosial berupa platform; (2) e-service quality, dapat menyediakan layanan konsultasi produk baik buah-buahan maupun sayuran dapat berupa call service dengan bebas pulsa atau melalui Whatsapp (WA); (3) review content, pemberian ketentuan untuk memberikan review pada produk di nyanyur.com sangat penting untuk menunjang kemajuan kinerjanya, untuk itu dapat diberi reward kepada konsumen yang memberikan review terbaik yang dapat mendukung aplikasi nyayur.com kedepannya, karena kebanyakan konsumen tidak memberikan review produk, setelah pembelian produk dari nyanyur.com.

\section{KESIMPULAN}

Social media marketing, e-service, dan review content tidak terbukti berpengaruh terhadap minat beli. Nyayur.com dapat menggunakan fasilitas premium dari platform yang digunakan. Strategi ini akan mampu mendongkrak tampilan Nyayur.com dalam iklan berdasarkan segmen potensial yang diklasifikasikan. Ini dianggap sebagai langkah paling efektif. Penelitian selanjutnya sebaiknya menggunakan variabel yang lebih spesifik seperti pada variabel review content bisa memilih rating atau review saja. Kelemahan dalam penelitian ini adalah penggunaan sampel mini yang tidak dapat mewakili jawaban dari permasalahan yang diajukan. Penelitian selanjutnya dapat menggunakan lebih dari satu UMKM Produk Organik sebagai objek untuk bisa mendapat lebih banyak responden.

\section{DAFTAR PUSTAKA}

Andini, C. (2016). Pengaruh E-Service Quality Terhadap Minat Beli Pengunjung Online Store Lazada Indonesia. E-Proceeding of Management, 3(2), 1289-1295.

Andrew, M. (2019). E-Service Quality dan Citra Merek Terhadap Minat Beli : Studi E-Service Quality dan Citra Merek Shopee. Jurnal Sekretaris Dan Administrasi Bisnis, 3(1), 23-28.

Bawono. Anton. 2006. Multivariate Analysis Dengan SPSS.Salatiga: STAIN Press.

Barriyah, Khoirul \& Suyanto AMA. (2019). Pengaruh E-Service Quality Terhadap Minat Beli Pengunjung Toko Online Shopee.co.id. e-Proceeding of Management. 6 (1), 321-329.

Bryan, \& Haryadi, E. (2018). Analisis Pengaruh Variabel Moderasi Switching Costs Terhadap Hubungan Service Performance Dan Customer Loyalty Member Celebrity Fitness Jakarta. Jurnal Manajemen, 15(1), 52-71.

Fajriani, Ayinda dan Sastika, Widya. 2016. Pengaruh Sosial Media Marketing Melalui Instagram Terhadap Minat Beli Konsumen Steak Ranjang Bandung (Studi Kasus Pada 
Bagus Satriyo, Yeni Indriana, \& Musalim Ridlo. Pẹrganuh Social Media Marketing, E-Service Quality, dan Review Content terhadap Minat Beli pada UMKM Produk Organik

Pengguna Instagram di Bandung Tahun 2016). Prosiding SnaPP Sosial, Ekonomi dan Humaniora. Vol. 6 No. 1. 124-133.

Farki, A. (2016). Pengaruh Online Customer Review dan Rating Terhadap Kepercayaan dan Minat Pembelian Pada Online Marketplace di Indonesia. Jurnal Teknik ITS, 5(2), A614-A619.

Ghozali, I. (2018). plikasi Analisis Multivariate dengan program IBM SPSS 25 edisi 9. Semarang: Badan Penerbit Universitas Diponegoro.

Giri, A., \& Millianyani, H. (2015). Pengaruh Social Media Marketing Melalui Instagram Terhadap Minat Beli Konsumen Sugar Tribe. EProceeding of Management, 2(3), 2581-2587.

Hasan, Ali \& Niken Widiati Setiyaningtiyas.(2015). Pengaruh Electronic Word of Mouth Pada Media Sosial Facebook Terhadap Keputusan Berkunjung Ke Desa Wisata Nglanggeran Gunung Kidul. Jurnal Media Wisata,13(1), 224-238.

Indika, D., \& Jovita, C. (2017). Media Sosial Instagram Sebagai Sarana Promosi Untuk Meningkatkan Minat Beli Konsumen. Jurnal Bisnis Terapan, 1(1), 25-31.

kominfo.go.id. (2017). UMKM Go Online, Upaya Wujudkan Visi "Digital Energy of Asia" . https://www.kominfo.go.id/content/detail/9514/umkm-go-online-upaya-wujudkan-visi-digitalenergy-of-asia/0/berita_satker. Diakses pada tanggal 16 November 2019

Kotler, Philip T., Keller, Kevin Lane. (2016). Marketing Management (15th ed). London: Pearson Education.

Kristiani, Paulani \& Diah Dhamaryanti. (2017). Pengaruh Social Media Marketing terhadap Repeat Purchase dengan Variabel Intervening Perceived Service Quality dan Brand Image pada Industri Fast-Food Restaurant di Surabaya. Petra Business \& Management Review. 3(1), 67-84.

Kurniawati, D., \& Nugraha, A. (2015). Strategi Pemasaran Melalui Media Sosial dan Minat Beli Mahasiswa. Jurnal Simbolika: Research and Learning in Community Study. 1(2), 193-198.

Kuspriyono, T., \& Nurelasari, E. (2018). Pengaruh Social Media Marketing Terhadap Customer Bonding dan Purchase to Intention. Cakrawala-Jurnal Humaniora, 18(2), 235-242.

Lupioyadi, R., \& Ihsan, R. (2015). Praktikum Metode Riset Bisnis. Jakarta: Salemba Empat.

Maulana, R., \& Kurniawan, K. (2014). Pengaruh Kualitas E-Service Terhadap Minat Beli Konsumen (Studi Kasus Pada Website Koren Denim). Jurnal Manajemen, 3(2), 117-129.

Mileva, L., \& Millianyani, H. (2018). Pengaruh Social Media Marketing Terhadap Keputusan Pembelian (Survei Online pada Mahasiswa Sarjana Jurusan Ilmu Administrasi Bisnis Angkatan 2014/2015 Fakultas Ilmu Administrasi Universitas Brawijaya yang Membeli Starbucks Menggunakan Line). Jurnal Administrasi Bisnis (JAB), 58(1), 190-199.

Mo, Z. (2015). Effect of Online Reviews on Consumer Purchase Behavior. Journal of Service Science and Management, 8, 419-424.

Natalie Robehmed. (2013). What is a Star Up. www.forbes.com/sites.natalierobehmed. 2013. what is astarup/\#5481792f4044. https://www.forbes.com/sites/natalierobehmed/\%202013/12/16/whatis-a-startup/. Diakses pada tanggal 15 November 2019.

Nasir, M., \& Harti. (2017). Pengaruh E-Service Quality dan Diskon Terhadap Minat Beli pada Situs Online di Website Zalora.co.id di Surabaya. Jurnal Pendidikan Tata Niaga, 1(1), 15-18. 
Nurlina. (2017). Pengaruh E-Service Quality dan Kepercayaan Online Terhadap Minat Pembelian Toko Online di Tokopedia. Jurnal Lentera Bisnis, 6(2), 83-93.

nyayur.com. (2019). Features. http://www.nyayur.com/. Diakses pada tanggal 16 November 2019.

Peter. J. Paul \& Olson. Jerry C. (1996). Consumer Bahaviour Perilaku Konsumen Dan Stategi Pemasaran. Jakarta: Erlangga.

Pramono, R., \& Augusty, F. (2012). Analisis Pengaruh Harga Kompetitif, Desain Produk dan Layanan Purna Jual Terhadap Minat Beli Konsumen Sepeda Motor Yamaha (Studi Kasus pada Masyarakat di Kota Semarang). Diponegoro Business Review, 1(1), 1-9.

Pratomo, Yudha. (2019). Jumlah Pengguna Internet di Indonesia mencapai 171 Jiwa. www.tekno.kompas.com. 2019. https://tekno.kompas.com/read/2019/05/16/03260037/apjiijumlah-pengguna-internet-di-indonesia-tembus-171-juta-jiwa. Diakses pada tanggal 15 November 2019.

Ramadhan, A. G., \& Santosa, S. B. (2017). Analisis Pengaruh Kualitas Produk, Kualitas Pelayanan, dan Citra Merek terhadap Minat Beli Ulang pada sepatu Nike Running di Semarang melalui Kepuasan Pelanggan sebagai Variabel Intervening. Diponegoro Journal of Management, 6(1), $1-12$.

Schiffman, \& Kanuk. (2008). Perilaku Konsumen. Jakarta: Indexs.

Sudaryono. (2016). Manajemen Pemasaran Teori dan Implementasi. Yogyakarta: Andi Offset.

Sugiyono. (2015). Metode Penelitian Kuantitatif, Kualitatif dan R\&D. Bandung: Alfabeta. 